ACTA AGROBOTANICA

Vol. 66 (4), 2013: 7-14

Reviews

DOI: $10.5586 / \mathrm{aa} .2013 .046$

\title{
THE ROLE OF Aegilops SPECIES IN THE ORIGIN AND IMPROVEMENT OF COMMON WHEAT
}

\author{
Roman Prażak \\ University of Life Sciences in Lublin, Subdepartment of Plant Biology, Faculty of Agricultural Sciences \\ Szczebrzeska 102, 22-400 Zamość, Poland \\ e-mail: roman.prazak@up.lublin.pl
}

Received: 22.04 .2013

\begin{abstract}
Some Aegilops species participated in wheat evolution playing a major role in wheat domestication and therefore the genus Aegilops represents a big part of the additional gene pool determining important traits of wheat. Breeders have been using these genes for many years to produce improved cultivars. Wide crosses between its wild relatives are sources of desirable characteristics for genetic improvement of common wheat. Triticum aestivum evolution and methods for transfer of alien material into wheat, briefly reviewed in this article, include incorporation of the whole genomes, single chromosomes, small chromosomal segments, single genes and cytoplasm substitution in wheat.
\end{abstract}

Key words: Aegilops, evolution, gene transfer, Triticum aestivum, wheat improvement, wide crosses

\section{Aegilops species as a source of valuable traits for common wheat}

In the last few decades, the biodiversity of cultivated wheat varieties has become significantly impoverished. It can be increased by introducing economically important genes from wild species, including genes from the genus Aegilops, to the wheat genome [1] The Aegilops and Triticum genera belong to the same family of grasses (Poaceae). Aegilops species are annual grasses characterized by strong tillering, found mainly in the Mediterranean Basin, southern Asia, the mountains of the Caucasus and Kashmir, and the Near East. They grow at various altitudes, from 0 to $2,000 \mathrm{~m}$, in dry and degraded environments, at field edges, on roadsides, in grassland, and in or near cultivated fields [2, 3].

Aegilops species are a source of valuable traits for wheat, including long ears [4]; a high content of protein, the amino acid lysine, and the macronutrients iron and zinc in the kernels $[5,6,7,8]$; resistance to rust $[9,10,11,12,13,14,15,16,17,18,19,20,21,22]$, to powdery mildew (Blumeria graminis) [23,24,25], to eyespot (Pseudocercosporella herpotrichoides) [26,27], to tan spot (Pyrenophora tritici-repentis) [28], to nematodes and insects [29,30,31], and to pre-harvest sprouting [32]; and tolerance for soil salinity, drought $[33,34]$ and soil acidification $[35,10]$.

An example of the transfer of beneficial traits from Aegilops species to cultivated wheat is the translocation from Ae. ventricosa introduced in France to the winter variety VPM1, conferring resistance - owing to the genes Pch1 and Pch2 - to eyespot, caused by Pseudocercosporella herpotrichoides [26]. In Great Britain an enzyme marker of the eyespot resistance gene was developed and the Rendezvous variety was produced, which is found in the lineage of many British, French, German and Swiss winter wheats as well as in Australian and North American wheats. In addition to resistance to Pseudocercosporella herpotrichoides, a translocation from Ae. ventricosa was also found to occur in these varieties, on chromosome $2 \mathrm{~B}$, containing a group of three rust resistance genes: $\mathrm{Lr} 37, \mathrm{Yr} 17$ and Sr 38 [36].

\section{The role of Aegilops species in the evolution of common wheat}

Both selection by man and natural cross-breeding between primitive wheats and wild grasses of the genus Aegilops occurring as weeds in wheat crops have played a significant role in the evolution of wheat. Some researchers estimate that hexaploid wheats evolved over 10,000 years [37]. The donor of the A genome for common wheat is probably the diploid wheat T. urartu [38]. The origin of the $\mathrm{B}$ genome is still a matter of controversy. $\mathrm{H} \mathrm{u}$ a n g et al. [39] believe it to be similar to the $\mathrm{S}$ genome of Aegilops species belonging 
to the Sitopsis section. The $\mathrm{S}$ genome of Ae. speltoides is most similar to the B genome of polyploid wheats. This can be seen in the fact that the brittle rachis gene $\mathrm{Br}_{3}$ has the same position on the short arm of chromosome $3 \mathrm{~S}$ in Ae. speltoides [40] and on the short arm of chromosome $3 \mathrm{~B}$ in the tetraploid wheat $T$. durum $[41,42]$. The locus of another brittle rachis gene, $B r_{2}$, was localized on the short arm of chromosome $3 \mathrm{~A}$ in T. durum [42]. The B genome, which originated in Ae. speltoides, probably underwent a secondary modification in wheat [43]. Tetraploid wheats (AABB) emerged as the result of chance pollination of Ae. speltoides with $T$. urartu pollen. Later, the number of chromosomes in the resulting hybrid must have doubled spontaneously. DNA analysis by $\mathrm{Haider}$ [44] revealed high similarity of the $\mathrm{S}$ genome of Ae. speltoides to the $\mathrm{B}$ genome of tetraploid and hexaploid wheat. Hexaploid wheats are presumed to have arisen from chance pollination of the tetraploid wheat $T$. dicoccoides with pollen of the diploid goatgrass Ae. squarrosa (Ae. tauschii) (DD), followed by spontaneous doubling of the number of chromosomes or the pairing of unreduced gametes in the resulting hybrid. Thus, they are natural amphiploids. The similarity between the $\mathrm{D}$ genomes of wheat and Ae. squarrosa can be seen in the position of the $B r_{l}$ brittle rachis gene on the short arm of chromosome 3D of T. aestivum and of the gene $\mathrm{Br}^{\prime}$ on the short arm of chromosome 3D in Ae. squarrosa (Ae. tauschii) [41,42].

\section{Methods and techniques of gene transfer from Aegilops species to common wheat}

Some Aegilops species occurring as weeds in wheat crops or on unploughed land between fields can spontaneously cross breed with common wheat [45]. The effectiveness of such spontaneous cross-breedings is similar to that of artificial ones. Seed setting in hybrids takes place more often when the maternal form is Aegilops and the paternal form is wheat [46,45,3]. Most easily cross-bred with wheat are Aegilops species containing the $\mathrm{D}$ genome, which has the highest homology to the D genome of wheat [3].

Failures in cross-breeding of wheat with many Aegilops species are due to low homology or lack of homology between their genomes and those of wheat, and to an improper number of chromosomes in the endosperm. Underdevelopment of the endosperm leads to the death of the embryos in the early stage of development. Embryos can be isolated and grown on artificial media in vitro. Sterility in $F_{1}$ hybrids of distant forms is due to disturbances in the meiosis process [47], which results in a lack of functional gametes. Backcrossing with wheat or colchicination is necessary to obtain kernels [48].
Difficulties in obtaining $F_{1}$ intergeneric hybrids also result from the genetic barrier posed by the group of $\mathrm{Kr}$ genes in common wheat. The system controlling the capacity for intergeneric cross-breeding of T. aestivum with rye includes four dominant genes, $K r 1, K r 2$, $\mathrm{Kr} 3$ and $\mathrm{Kr} 4$, of which $\mathrm{Krl}$ produces the strongest effect and $K r 3$ the weakest. In their dominant form, these genes inhibit seed-setting ability in the $\mathrm{F}_{1}$ generation $[49,50,51]$. There are, however, varieties of wheat, e.g. Chinese Spring with the genotype $k r 1 k r l k r 2 k r 2$, which are distinguished by adequate ability to cross breed with rye [52].

To overcome barriers to cross-breeding, various methods and techniques are used for transferring genes from Aegilops species to wheat. These include the following:

- adding the entire genome of the Aegilops species to wheat genomes, i.e. obtaining amphiploids, and from these, via backcrossing with wheat, addition and substitution lines;

- one of the recombination methods, i.e. crossover resulting from homologous or homeologous pairing of chromosomes;

- translocations induced by ionizing radiation, caused by gametocidal chromosomes, or resulting from somaclonal variation;

- obtaining alloplasmic forms of wheat with the cytoplasm of Aegilops species;

- transferring single genes to wheat via genetic engineering methods.

Chromosome doubling using colchicin in $F_{1}$ hybrids makes it possible to obtain amphiploids [53], and from these, via backcrossing with wheat, addition and substitution lines [54,55]. Amphiploids can also arise spontaneously via pairing of unreduced male and female gametes formed by intergeneric or interspecific $\mathrm{F}_{1}$ hybrids [56].

By backcrossing amphiploids with wheat and carrying out selection for 43-chromosome plants, addition lines can be produced. One Aegilops chromosome is added to the complete set of wheat chromosomes, and following pollination of plants with 43 chromosomes, forms arise that have two Aegilops chromosomes. Although addition lines have not found wide application in practice due to disturbances in meiotic divisions leading to the loss of the added chromosome and to low fertility, they are used to identify foreign chromosomes and as initial forms for transferring foreign genetic material to wheat $[55,57]$.

Addition lines are used to obtain substitution lines. These are more stable than addition lines and have more genotypic variation. Substitution lines were obtained in which Aegilops chromosomes were substituted in place of wheat chromosomes $[6,58,59,60]$. Owing 
to the foreign chromosomes, these lines are resistant to fungal pathogens, nematodes, and insects.

The simplest method for transferring foreign genes to wheat is recombination resulting from homologous pairing of chromosomes, usually chromosome D of Aegilops and chromosome D of wheat [3]. The species Ae. squarrosa $(\mathrm{D})$, Ae. ventricosa $(\mathrm{UnD})$, and Ae. cylindrica $(\mathrm{CD})$ contain $\mathrm{D}$ genomes that are homologous to that of wheat [2]. In this case, gene transfer can take place on the basis of a simple crossing over.

Recombination resulting from homeologous pairing of chromosomes occurs exclusively via inactivation of the $P h$ genes of the homologous pairing system in common wheat. Suppression of homeologous pairing is controlled by the group of dominant $P h$ genes - Phl on chromosome $5 \mathrm{BL}$ and $P h 2$ on chromosome 3DS, as well as other unidentified genes on chromosomes 3AS, 4D, 5A, 5B, and 5D. Of these, Phl exhibits the strongest effect [61]. The gene $P h l$ occurs both in common wheat $T$. aestivum and in tetraploid wheat $T$. durum, but is not present in diploid species of wheat or in the Aegilops species from which tetraploid wheats with AABB and AAGG genomes were produced. This gene must have appeared at the tetraploid level in the development of hexaploid wheat. The absence of the $P h l$ gene in the goatgrass Ae. speltoides indicates that it emerged as the recessive mutation $p h$, enabling pairing of chromosomes of diploid wheat (AA) with chromosomes of Ae. speltoides (SS), or as a translocation of a segment of an extra chromosome of the goatgrass Ae. mutica with a wheat chromosome [62].

In the absence of dominant $P h$ genes (nullisomy $2 \mathrm{n}=40: p h p h$, monosomy $2 \mathrm{n}=41: P h p h)$ or in the case of a recessive mutation (disomy $2 \mathrm{n}=42$ : $p h p h$ ), there occurs homeologous pairing of chromosomes of foreign species with wheat chromosomes in $\mathrm{F}_{1}$ hybrids. The effect of the recessive $p h$ allele is manifested only in interspecific and intergeneric hybrids; it does not affect the pairing of chromosomes of the A, B and D genomes in common wheat [63]. During homeologous pairing reciprocal translocations take place, which constitute the main mechanism by which a chromosome fragment from a foreign species is incorporated in the wheat genome, and the transfer of foreign genes sought in T. aestivum breeding occurs. Thus, the system of recessive $p h$ genes enabling homeologous pairing is exploited in the introgression of foreign genes into common wheat. For this reason work has been undertaken to obtain recessive $p h p h$ genotypes in $T$. aestivum wheat [52]. S e a r s [64] obtained the world's first complete sets of 21 monosomic lines $(2 n=$ $41)$ and 21 nullisomic lines $(2 n=40)$ in the Chinese Spring variety. This allowed the heterozygous genotypes Phlph1 (mono-5B) and Ph2ph2 (mono-3D) and the homozygous genotypes phlphl (nulli-5B) and $p h 2$ ph2 (nulli-3D) to be used in breeding. Subsequent monosomic series of wheat were obtained in the cultivars 'Drabant', 'Jara', 'Favorit' and others [52].

Using induced homeologous pairing and crossing over, a number of wheat varieties with Aegilops genes have been obtained. One of the first was Compair [65], with resistance to yellow rust transferred from Ae. comosa. Resistance to rust was determined by the dominant gene transferred to chromosome 2D of wheat together with a fragment of chromosome $2 \mathrm{M}$ of Ae. comosa.

On chromosome $5 \mathrm{~S}$ of the goatgrass Ae. Speltoides, Dvorak et al. [61] identified dominant $P h^{I}$ suppressor genes which cause inactivation of the gene $P h 1$ on chromosome 5BL of common wheat. In the presence of these genes, and despite the presence of the $P h 1$ gene, synapsis takes place between homeologous chromosomes of foreign species and of T. aestivum. Similar genes were located in Ae. peregrina and Ae. kotschyi [66]. Suppressor genes were successfully used to transfer genes of resistance to brown and yellow rust from Ae. umbellulata [14] and from Ae. triuncialis and Ae. geniculata [67] to common wheat.

Sears [68] distinguished goatgrass species whose $\mathrm{S}$ genomes were highly homeologous to wheat B genomes: $A e$. searsii $\left(\mathrm{S}^{\mathrm{S}}\right), A e$. longissima $\left(\mathrm{S}^{1}\right)$, Ae. sharonensis $\left(\mathrm{S}^{1}\right)$, Ae. bicornis $\left(\mathrm{S}^{\mathrm{b}}\right)$, Ae. speltoides (S), Ae. variabilis (US) and Ae. kotschyi (US). The author states that a low degree of homeology to wheat genomes is exhibited by the genomes of such species as Ae. umbellulata (U), Ae. mutica (Mu), Ae. caudata (C), Ae. comosa (M) and Ae. uniaristata (Un).

If a foreign chromosome is not homeologous to wheat chromosomes and cannot pair with them in $\mathrm{F}_{1}$ hybrids, genetic material from Aegilops can be introduced into wheat by means of translocations. It is then necessary to apply radiation methods in order to physically activate the chromosome [69]. These methods involve irradiation of the anthers or kernels of $F_{1}$ hybrids and self-pollination. In both cases, in the $\mathrm{F}_{2}$ generation translocations with a foreign chromosome must be identified $[70,52]$. S e a r s [71] was the first to use ionizing radiation to induce chromosomal aberrations and to transfer the gene for resistance to brown rust (Puccinia recondita) from Ae. umbellulata to the Chinese Spring variety of wheat.

Gametocidal chromosomes can contribute to the transfer of foreign genes to wheat. It has been observed that certain foreign chromosomes added to wheat are not eliminated from its genome despite successive backcrossings. Gametes with such chromosomes were found to be fertile, while other gametes were incapable of fertilization. The presence of a gene or genes conferring the 'gametocidal' trait was observed on chromosome $3 \mathrm{C}$ of Ae. markgrafii and Ae. triuncialis [72], on chromosome 2C of Ae. cylindrica [73], on chromosome $4 \mathrm{M}$ of 
Ae. geniculata [74], on chromosomes $2 \mathrm{~S}^{1}$ and $4 \mathrm{~S}^{1}$ of Ae. longissima, on $2 \mathrm{~S}^{\mathrm{sh}}$ and $4 \mathrm{~S}^{\mathrm{sh}}$ of Ae. sharonensis [75], and on chromosomes $2 \mathrm{~S}$ and $6 \mathrm{~S}$ of Ae. speltoides [76]. Gametocidal chromosomes introduced into wheat induced mutations involving structural changes in chromosomes such as deletions and translocations [77].

In vitro breeding conditions can also contribute to translocations between Aegilops and Triticum chromosomes. Fe ld man [78] observed the presence of multivalents in meiosis, probably caused by translocations in hybrids of $T$. aestivum with the amphiploid $T$. turgidum-Ae. squarrosa, regenerated from callus obtained from an in vitro microspore culture.

Aegilops species can be used as donors of cytoplasmic genes. As a result of the transfer of the common wheat nucleus to the cytoplasm of Ae. caudata and Ae. ovata, in later generations of backcrossing hybrids there appeared male-sterile forms of wheat that could constitute starting material in heterosis breeding [79]. Cytoplasm substitution can cause changes in grain yield, protein content and resistance to various biological and ecological stresses, due to diverse interactions between the nucleus and the cytoplasm [80]. By cross-breeding the species Ae. caudata, Ae. columnaris, Ae. kotschyi, Ae. markgrafii, Ae. peregrina, Ae. umbellulata and Ae. triuncialis with alloplasmic wheat with a translocated 1BL/1RS chromosome, wheat haploids can be induced as the result of parthenogenesis [81]. From these haploids it is possible to obtain double haploids, by colchicination or the use of other mutagens that double genetic material, thus substantially shortening the process of producing new varieties.

Recent years have seen the rapid development of genetic engineering techniques. Transgenic varieties of wheat have been obtained which are resistant to the herbicide glyphosate [82]. One subject of current research is the risk of transfer of such transgenes from wheat to Aegilops species, which are often present as weeds in wheat crops [45]. Genetic markers can be used to evaluate the scale of this phenomenon. Areas in which DNA markers have found wide application include evaluation of genetic similarity or distance, selection and identification of desired forms, confirmation of the effectiveness of cross-breeding, and identification of Aegilops genes determining important performance features $[36,83,84,57,85,86,87,17$, 88]. Using molecular techniques, Aegilops genes can be isolated and stored in artificial bacterial chromosomes and then transferred to wheat $[89,90]$.

\section{CONCLUSION}

Transfer of Aegilops genes makes it possible to enrich wheat with valuable resistance and quality characteristics and to prevent genetic erosion of the species. The modifications and breeding lines obtained constitute starting material for new varieties which are more fertile, more resistant, and better suited to changing climate and soil conditions.

\section{Acknowledgments}

This work was supported by the Subdepartment of Plant Biology, Faculty of Agricultural Sciences, University of Life Sciences in Lublin.

\section{References}

1. Feld man M. Gene transfer from wild species into cultivated plants. Genetics. 1983; 15(2): 145-161.

2. Kimber G, Feldman M. Wild Wheat: An Introduction. College of Agriculture, University of Missouri, Columbia, Special Report. 1987; 353: 1-146.

3. Kilian B, Mammen K, Millet E, Sharma R, Graner A, Salamini F, Hammer K, Özkan H. Aegilops. [In:] Wild crop relatives: genomic and breeding resources cereals. Chittaranjan Kole (ed.), Springer-Verlag Berlin, Heidelberg, 2011: 1-76.

4. Millet E, Avivi Y, Zaccani M, Feldman M. 1988. The effect of substitution of chromosome 5S of Aegilops longissima for its wheat homoeologus on spike morphology and on several quantitative traits. Genome. 1988; 30: 473-478.

5. Blüthner WD, Schumann E. Use of Aegilops and tetraploid wheat for wheat protein improvement. Hod Roślin Aklim Nasien. 1988; 32 (1/2): 203-206.

6. Pestsova EG, Börner A, Röder MS. Development of a set of Triticum aestivum-Aegilops tauschii introgression lines. Hereditas. 2001; 135 (2-3): 139-143. http:// doi:10.1111/j.1601-5223.2001.00139.x

7. Pra żak R. Porównanie zawartości białka w ziarnie gatunków Aegilops i Triticum. / Comparision of protein content in the grain of Aegilops and Triticum. Zesz Probl Post Nauk Rol. 2004; 497: 509-516. (in Polish)

8. Rawat N, Tiwari VK, Singh N, Randhawa GS, Singh K, Chhuneja P, Dhaliwal HS. Evaluation and utilization of Aegilops and wild Triticum species for enhancing iron and zinc content in wheat. Genet Resour Crop Evol. 2009; 56: 53-64. http://doi:10.1007/s10722-00 8-9344-8

9. Frauenstein K, Ha m mer K. Prüfung von Aegilops - Arten auf Resistenz gegen Echten Mehltau, Erysiphe graminis D. C., Braunrost, Puccinia recondita Rob. ex Desm. und Spelzenbraune, Septoria nodorum Berk. Kulturpflanze 1985; 33: 155-163. (in German)

10. Stefanowska G, Prażak R, Strzembicka A, Masłowski J. Transfer genów z Aegilops ventricosa Tausch. i Aegilops juvenalis (Thell.) Eig. do Triticum aestivum L. / Gene transfer from of Aegilops ventricosa Tausch. and Aegilops juvenalis (Thell.) Eig. to Triticum aestivum L. Biul IHAR 1995; 194 : 45-52. (in Polish) 
11. Prażak R. Evaluation of brown rust (Puccinia recondita f. sp. tritici) infection in Aegilops species and Triticum aestivum L. cv. Gama. J Appl Genet. 1997; 38 B: 123-127.

12. Özgen M, Yildiz M, Ulukan H, Koyuncu N. Association of gliadin protein pattern and rust resistance derived from Aegilops umbellulata Zhuk. in winter Triticum durum Desf. Breed Sci. 2004; 54: 287-290.

13. Singh S, Franks CD, Huang L, Brown-Guedira GL, Marshall DS, Gill BS, Fritz A. Lr41, Lr39, and a leaf rust resistance gene from Aegilops cylindrica may be allelic and are located on wheat chromosome 2DS. Theor Appl Genet. 2004; 108: 586-591. http://doi:10.1007/ s00122-003-1477-8

14. Chhuneja P, Kaur S, Goel RK, Aghaee-Sarbarzeh M, Prashar M, Dhaliwal HS. Transfer of leaf rust and strip rust resistance from Aegilops umbellulata Zhuk. to bread wheat (Triticum aestivum L.). Genet ResourCrop Evol. 2008; 55: 849-859. http://doi:10.1007/s10722-0 07-9289-3

15. Bossolini E, Krattinger SG, Keller B. Development of simple sequence repeat markers specific for the Lr34 resistance region of wheat using sequence information from rice and Aegilops tauschii. Theor Appl Genet. 2006; 113: 1049-1062. http://doi:10.1007/s00122-006-0364-5

16. Kuraparthy V, Sood S, Chluneja P, Dhaliwal SH, Kaur S, Bowden RL, Gill BS. A cryptic wheat-Aegilops triuncialis translocation with leaf rust resistance gene Lr58. Crop Sci. 2007; 47: 1995-2003. http://doi: 10.2135/cropsci2007.01.0038

17. Kuraparthy V, Chluneja P, Dhaliwal SH, Kaur S, Bowden RL, Gill BS. Characterization and maping of cryptic alien introgression from Aegilops geniculata with new leaf rust and stripe rust resistance genes $L r 57$ and $Y r 40$ in wheat. Theor Appl Genet. 2007; 114: 1379-1389. http://doi:10.1007/s00122-007-0524-2

18. Marais GF, McCallum B, Snyman JE, Pretorius ZA, Marais AS. Leaf rust and stripe rust resistance genes $\operatorname{Lr} 54$ and Yr37 transferred to wheat from Aegilops kotschyi. Plant Breed. 2005; 143: 115-123. http:// doi:10.1007/s10681-006-9092-9

19. Marais GF, McCallum B, Marais AS. Leaf rust and stripe rust resistance genes derived from Aegilops sharonensis. Euphytica. 2006; 149: 373-380. http://doi:10.10 07/s10681-006-9092-9

20. Marais GF, McCallum B, Marais AS. Wheat leaf rust resistance gene Lr59 derived from Aegilops peregrina. Plant Breed. 2008; 127 (4): 340-345. http://doi:10. 1111/j.1439-0523.2008.01513.x

21. Marais GF, Marais AS, McCallum B, Pretorius $\mathrm{ZA}$. Transfer of leaf rust and stripe rust resistance genes Lr62 and Yr42 from Aegilops neglecta Req. ex Bertol. to common wheat. Crop Sci. 2009; 49 (3): 871-879. http://doi:10.2135/cropsci2008.06.0317

22. Marais GF, Badenhorst PE, Eksteen A, Pretorius Z A. Reduction of Aegilops sharonensis chromatin associated with resistance genes Lr56 and Yr38 in wheat. Euphytica. 2010; 171 (1): 15-22. http://doi:10.1007/ s10681-009-9973-9
23. Spetsov P, Mingeot D, Jacquemin JM, Samardijeva K, Marinova E. Transfer of powdery mildew resistance from Aegilops variabilis into bread wheat. Euphytica. 1997; 93: 49-54.

24. Stoilova T, Spets ov P. Chromosome $6 \mathrm{U}$ from Aegilops geniculata Roth carrying powdery mildew resistance in bread wheat. Breed Sci. 2006; 56: 351-357.

25. Miranda LM, Murphy JP, Marshall D, Cowger C, Leath S. Chromosomal location of Pm35, a novel Aegilops tauschii derived powdery mildew resistance gene introgressed into common wheat (Triticum aestivum L.). Theor Appl Genet. 2007; 114 (8), 1451-1456. http:// doi:10.1007/s00122-007-0530-4

26. Doussinault G, Delibes A, Sanchez-Monge R, Garcia-Olmedo F. Transfer of a dominant gene for resistance to eyespot disease from a wild grass to hexaploid wheat. Nature. 1983; 303: 698-700.

27. Thiele A, Schumann E, Peil A, Weber WE. Eyespot resistance in wheat $\mathrm{x}$ Aegilops kotschyi backcross lines. Plant Breed. 2002; 121: 29-35. http://doi:10. 1046/j.1439-0523.2002.00669.x

28. Tadesse W, Hsam SLK, Wenzel G, Zeller F J . Identification and monosomic analysis of tan spot resistance genes in synthetic wheat lines (Triticum turgidum L. × Aegilops tauschii Coss.). Crop Sci. 2006; 46: 1212-1217.

29. Martín-Sánchez JA, Gómez-Colmenarejo M, Del Moral J, Sin. E, Montes MJ, GonzálezBelinchón C, López-Brańa I, Delibes A. A new Hessian fly resistance gene (H30) transferred from the wild grass Aegilops triuncialis to hexaploid wheat. Theor Appl Genet. 2003; 106: 1248-1255.

30. Montes MJ, Andrés MF, Sin E, López-Brańa I, Martin-Sánchez JA, Romero MD, Delibes A. Cereal cyst nematode resistance conferred by the $\mathrm{Cre} 7$ gene from Aegilops triuncialis and its relationship with Cre genes from Australian wheat cultivars. Genome. 2008; 51(5): 315-319. http://doi:10.1139/G08-015

31. Coriton O, Barloy D, Huteau V, Lemoine J, Tanguy A, Jahier J. Assignment of Aegilops variabilis Eig chromosomes and translocations carrying resistance to nematodes in wheat. Genome. 2009; 52 (4): 338-346. http:// doi:10.1139/g09-011

32. Gatford KT, Hearnden P, Ogbonnaya F, Eastwood RF, Halloran GM. Novel resistance to pre-harvest sprouting in Australian wheat from the wild relative Triticum tauschii. Euphytica. 2002; 126: 67-76.

33. Shimshi D, Mayoral ML, Atsmon D. 1982. Response to water stress in wheat and related wild species. Crop Sci. 1982; 22: 123-128.

34. Farooq S, Iqbal N, Asghar M, Shah TM. Intergeneric hybridization for wheat improvement - IV. Expression of salt tolerance gene (s) of Aegilops cylindri$c a$ in hybrids with hexaploid wheat. Cer Res Comm. 1992; 20(1-2): 111-118.

35. B erzonsky WA, Kimber G. The tolerance to aluminium of Triticum N-genome amphiploides. Plant Breed. 1989; 103: 37-42. 
36. Chełkowski J, Stępień Ł, Błaszczyk L. Możliwości wykorzystania markerów DNA w hodowli odpornościowej pszenicy. Hod Roślin Nasien. 2004; 2: 8-13. (in Polish)

37. Goncharov NP, Golovnina KA, Kilian B, Glushkov S, Blinov A, Shumny VK. Evolutionary history of wheats - the main cereal of mankind. [In:] Biosphere origin and evolution (ed.) DN Springer. 2008; 6: 407-419.

38. Gulbitti-Onarici S, Sumer S, Ozcan S. Phylogenetic relationships among some wild wheat species revealed by AFLP markers. Bot J Linn Soc. 2007; 153: 67-72.

39. Huang Z, Long H, Wei YM, Qi PF, Yan ZH., Zheng YL. Characterization and classification of g-gliadin multigene sequences from Aegilops section Sitopsis. Cereal Res Commun. 2010; 38(1): 1-14. http://doi:10.1556/ CRC.38.2010.1.1

40. Watanabe N, Sugiyama K, Yamagishi Y, $\mathrm{S}$ akat a Y. Comparative telosomic mapping of homoeologous genes for brittle rachis in tetraploid and hexaploid wheat. Hereditas. 2010; 137(3): 180-185. http://doi: 10.1034/j.1601-5223.2002.01609.x

41. Watanabe N, Takesada N, Shibata Y, Ban T. Genetic mapping of the genes for glaucous Lear and tough rachis in Aegilops tauschii, the D-genome progenitur of wheat. Euphytica. 2005; 144; 119-123. http://doi:10.1007/ s10681-005-5193-0

42. Watanabe N, Fuji Y, Kato N, Ban T, Martinek P. Microsatellite mapping of the genes for brittle rachis on homoeologous group 3 chromosomes in tetraploid and hexaploid wheats. J Appl Genet. 2006; 47(2): 93-98.

43. Zhang L, Liu D, Lan X, Zheng Y, Yan Z. A synthetic wheat with 56 chromosomes derived from Triticum turgidum and Aegilops tauschii. J Appl Genet. 2008; 49(1): 41-44.

44. Haider N. Evidence for the origin of the B genome of bread wheat based on chloroplast DNA. Turk. J Agric For. 2012; 36: 13-25. http://doi:10.3906/tar-1011-1394

45. Zaharieva M, Monneveux P. Spontaneous hybridization between bread wheat (Triticum aestivum L.) and its wild relatives in Europe. Crop Sci. 2005; 46 (2): 512-527.

46. P r a ż a k R. Cross direction for successful production of $F_{1}$ hybrids between Triticum and Aegilops species. Plant Breed Seed Sci. 2001; 45(1): 83-86.

47. Stefanowska G, Prażak R, Kosińska D. Hybrids of Aegilops cylindrica Host., Aegilops juvenalis (Thell.) Eig. and Aegilops triaristata Willd. 6x with Triticum aestivum L. Plant Breed Seed Sci. 1998; 42/ 2: 3-18.

48. Sh a r m a HC. How wide can a wide cross be? Euphytica 1995; 82: 43-64.

49. Le in A. Die genetische Grundlage der Kreuzbarkeit Zwischen Weizen und Roggen. Z. Vererbungsl. 1943; 81: 28-61.

50. Krolow KD. Untersuchungen über die Kreuzbarkeit zwischen Weizen und Roggen. Z. Pflanzenzücht. 1970; 6: 44-72.

51. Luo MC, Yen C, Yang JL. Crossability percentages of bread wheat landraces from Shanxi and Henan provinces China with rye. Euphytica. 1993; 67: 1-8.

52. Pilch J. Możliwości wykorzystania krzyżowania introgresywnego w hodowli pszenicy ozimej Triticum aestivum L. Część I. Zastosowanie systemów genetycznych pszenicy T. aestivum L. do otrzymania mieszańców pomostowych $\mathrm{F}_{1}$. / Possibilities of using of introgressive hybridization in breeding of winter wheat T. aestivum L. Part I. Utilization of the genetic systems of wheat T. aestivum L. for obtaining the F1-bridge hybrids. Biul. IHAR 2005; 235: 31-41. (in Polish)

53. Tiwari VK, Rawat N, Neelam K, Randhawa G, Singh K, Chuneja P, Dhaliwal HS. Development of Triticum turgidum subsp. durum-Aegilops longissima amphiploids with high iron and zinc content through unreduced gamete formation in $\mathrm{F}_{1}$ hybrids. Genome. 2008; 51(9): 757-766. http://doi:10.1139/G08-057

54. Özkan H, Tuna M, Arumuganathan K. Nonadditive changes in genome size during allopolyploidization in the wheat (Aegilops-Triticum) group. J Heredity. 2003; 94(3): 260-264. http://doi: 10.1093/jhered/esg053

55. Tyankova ND, Zagorska NA, Dimitrov B. Callus induction and organogenesis in wheat/Aegilops longissima chromosome addition lines. Plant Cell, Tissue and Organ Culture. 2003; 72: 193-197.

56. Fukuda K, Saka moto S. Studies on unreduced gamete formation in hybrids between tetraploids wheats and Aegilops squarrosa. Hereditas. 1992; 116: 253-255.

57. Schneider A., Linc G., Molnár I., MolnárLáng M. Molecular cytogenetic characterization of Aegilops biuncialis and identification of five derived wheat Aegilops biuncialis disomic chromosome addition lines. Genome. 2005; 48: 1070-1082. http://doi:10.1139/g05-062.

58. Adonina IG, Salina EE, Efremova TT, Pshenichnikova TA. The study of introgressive lines of Triticum aestivum $\mathrm{x}$ Aegilops speltoides by in situ and SSR analyses. Plant Breed. 2004; 123(3): 220-224.

59. Zhu Z, Zhou R, Kong X, Dong Y, Jia J. Microsatellite marker identification of a Triticum aestivum - Aegilops umbellulata substitution line with powdery mildew resistance. Euphytica. 2006; 150(1-2): 149-153. http:// dx.doi:org/10.1007/s10681-006-9103-x

60. Delibes A., López-Brań I., Moreno-Vázquez S., Martin-Sanchez J.A. Reviev. Characterization and selection of hexaploid wheats containing resistance to Heterodera avenae or Mayetiola destructor introgressed from Aegilops. Spanish J Agr Res. 2008; 6: 81-87.

61. Dvorak J, Deal KR, Luo MC. Discovery and mapping of wheat $\mathrm{Ph} 1$ suppressors. Genetics. 2006; 174(1): 17-27. http://doi:10.1534/genetics.106.058115

62. Dover GA, Riley R. Prevention of pairing of homoeologous meiotic chromosomes of wheat by an activity of supernumerary chromosomes of Aegilops. Nature. 1972; 240: $159-161$.

63. Riley R, Chapman V, Miller TE. The determination of meiotic chromosome pairing. Proc. $4^{\text {th }}$ Int. Wheat 
Genet. Symp. Univ. Columbia. MO. 1973: 731-738.

64. S e ar s ER. 1954. The systematic, cytology and genetics of wheat. Res Bull Mis Agric Exptl Stat. 1954; 572: 1-58.

65. Riley R, Chapman V, Johnson R. Introduction of yellow rust resistance of Aegilops comosa in wheat by genetically induced homoeologous recombination. Nature. 1968; 217: 383-384.

66. Fernández-Calvín B, Orellana J. Metaphase-I bound-arm frequency and genome analysis in wheat-Aegilops hybrids. 1. Ae. variabilis-wheat and Ae. kotschyi-wheat hybrids with low and high homoeologous pairing. Theor Appl Genet. 1991; 83: 264-272.

67. Aghaee-Sarbarzeh M, Ferrahi M, Singh S, Singh H, Friebe B, Gill BS. Ph-I-induced transfer of leaf and stripe rust-resistance genes from Aegilops triuncialis and Ae. geniculata to bread wheat. Euphytica. 2002; 127: 377-382.

68. S e ar s ER. Transfer of alien genetic material to wheat. P. 75-89. [In:] Evans L.T. Peacock W.J. (eds). Wheat Science - Today and Tomorrow. Cambridge University Press, Cambridge; 1981.

69. Molnár I, Benavente E, Molnár-Láng M. Detection of intergenomic chromosome rearrangements in irradiated Triticum aestivum -Aegilops biuncialis amphiploids by multicolour genomic in situ hybridization. Genome. 2009; 52(2): 156-165. http://doi:10.1139/G08-114

70. Driscoll C.J., Jensen N.F. A genetic method for detecting induced intergeneric translocations. Genetics. 1963; 48: 459-468.

71. S e a r s ER. The transfer of leaf rust resistance from Aegilops umbellulata to wheat. Brookhaven Symp Biol. 1956; 9: 1-22.

72. Endo TR, Tsunewaki K. Sterility of common wheat with Aegilops triuncialis cytoplasm. J Hered. 1975; 66: $13-18$.

73. Endo T.R. Selective gametocidal action of a chromosome of Aegilops cylindrica in a cultivar of common wheat. Wheat Inf Serv. 1979; 50: 24-28.

74. Kynast RG., Friebe B, Gill B S. Fate of multicentric and ring chromosomes induced by a new gametocidal factor located on chromosome $4 \mathrm{Mg}$ of Aegilops geniculata. Chrom Res. 2000; 8: 133-139.

75. Endo, TR. Two types of gametocidal chromosome of Aegilops sharonensis and Aegilops longissima. Jn J Genet. 1985; 60: 125-135.

76. Marais GF., Bekker TA, Eksteen A, McCallum B, Fetch T, Marais AS. Attempts to remove gametocidal genes co-transferred to common wheat with rust resistance from Aegilops speltoides. Euphytica. 2010; 171 (1): 71-85.

77.Friebe B, Zhang P, Nasuda S, Gill BS.Characterization of a knock-out mutation at the $G c 2$ locus in wheat. Chromosoma. 2003; 111: 509-517. http://doi:10.1007/ s00412-003-0234-8
78. Feldman M. Cytogenetic and molecular approaches to alien gene transfer in wheat. Proc. of the Seventh Int. Wheat Genet Symp. 1988; 1: 23-32.

79. Hoffman W, Mudra A, Plarre W. Ogólna hodowla roślin. PWRiL, Warszawa; 1976. (in Polish)

80. Kih a r H. Wheat studies - retrospect and prospects. Elsevier Scientific Publishing Company, Amsterdam, 1982.

81. Tsunewaki K, Endo TR, Mukai Y. Further discovery of alien cytoplasms inducing haploids and twins in common wheat. Theor Appl Genet. 1974; 45 (3): 104-109.

82. Blachshaw RE, Harker KN, Clayton GW, O'D on ovan J.T. Broadleaf herbicide effects on clethodim and quizalofop-P efficacy on volunteer wheat (Triticum aestivum). Weed Technology 2006; 20 (1): 221-226.

83. Helguera M, Vanzetti L, Soria M, Khan IA, Kolmer J, Dubcovsky J. PCR markers for Triticum speltoides leaf rust resistance gene $L r 51$ and their use to develop isogenic hard red spring wheat lines. Crop Sci. 2005; 45: 728-734. http://escholarship.org/uc/item/0991z3tb

84. Gupta SK, Charpe A, Koul S, Prabhu KV, $\mathrm{Ha}$ QMR. Development and validation of molecular markers linked to an Aegilops umbellulata-derived leaf rust- resistance gene, $\operatorname{Lr} 9$, for marker-assisted selection in bread wheat. Genome. 2005; 48 (5): 823-830. http://doi:10.1139/ g05-051

85. Golovnina KA, Glushkov SA, Blinov AG, Mayorov VI, Adkinson LR, Goncharov NP. Molecular phylogeny of the genus Triticum L. Plant Syst Evol. 2007; 264: 195-216. http://doi:10.1007/s00606-0060478-x

86. Haider N, Nabulski I. Identification of Aegilops L. species and Triticum aestivum L. based on chloroplast DNA. Genet Resour Crop Evol. 2008; 55: 537-549. http:// doi:10.1007/s10722-007-9259-9

87. Gulbitti-Onarici S, Sancak C, Sumer S, O z c a n S. Phylogenetic relationships of some wild wheat species based on the internal transcribed spacer sequences of nrDNA. Curr Sci. 2009; 96(6): 794-800.

88. Song W, Xie H, Liu Q, Chaojie X, Ni Z, Yang T, Sun Q, Liu Z. Molecular identification of Pm 12 - carrying introgression lines in wheat using genomic and EST-SSR markers. Euphytica. 2007; 158: 95-102. http://doi:10.1007/s10681-007-9432-4

89. Loeb T.A., Spring L.M., Steck T. R., Reynolds T.L. Transgenic wheat (Triticum spp.). [In:] Biotechnology in Agriculture and Forestry 46. Transgenic Crops I. Bajaj Y.P.S. (ed.). Springer-Verlag Berlin Heidelberg, 2000: 14-36.

90. Akhunov E, Akhunova A, Dvorak J. BAC libraries of Triticum urartu, Aegilops speltoides and Ae. tauschii, the diploid ancestors of polyploid wheat. Theor Appl Genet. 2005; 111: 1617-1622. http://doi:10.1007/s00122-0 05-0093-1 
Udział gatunków Aegilops

w powstaniu i doskonaleniu pszenicy zwyczajnej

\section{Streszczenie}

Niektóre gatunki Aegilops brały udział w ewolucji pszenicy zwyczajnej, odgrywając ważną rolę w jej udomowieniu, dlatego rodzaj Aegilops stanowi dużą część dodatkowej puli genów warunkujących ważne cechy użytkowe dla pszenicy. Hodowcy od lat wykorzystują te geny do tworzenia nowych dosko- nalszych odmian pszenicy. Krzyżowania oddalone napotykają na szereg barier niekrzyżowalności, które należy pokonać, aby uzyskać mieszańce, a następnie wyselekcjonować z nich linie charakteryzujące się pożądanymi cechami dzikich krewniaków pszenicy. $\mathrm{W}$ artykule przedstawiono doniesienia na temat ewolucji pszenicy zwyczajnej oraz główne metody i techniki umożliwiające transfer materiału genetycznego gatunków Aegilops do pszenicy, w tym dodawanie całych genomów, pojedynczych chromosomów, fragmentów chromosomów, pojedynczych genów oraz substytucję cytoplazmy w pszenicy.

Handling Editor: Elżbieta Weryszko-Chmielewska

This is an Open Access digital version of the article distributed under the terms of the Creative Commons Attribution 3.0 License (creativecommons.org/licenses/by/3.0/), which permits redistribution, commercial and non-commercial, provided that the article is properly cited.

CThe Author(s) 2013 Published by Polish Botanical Society 